\title{
Identifikasi Kemampuan Literasi Matematika Siswa Kelas IX SMP Dalam Menyelesaikan Soal PISA Konten Space and Shape
}

Author:
Allifia Nindya Oktaviani
Susanto
Titik Sugiarti
Wiwik Indiyawati
Affiliation:
$1,2,3$ Mathematics Education,
University of Jember, East
Java Indonesia.
${ }^{4}$ SMPN 1 Rambipuji
Jember,
East Java, Indonesia.
Corresponding author:
Allifia Nindya Oktaviani
allifianindyao@ gmail.com
Dates:
Received: $7 / 10 / 2021$
Accepted: $21 / 11 / 2021$
Published: $30 / 11 / 2021$

\begin{abstract}
Abstrak. Penelitian ini dilatar belakangi oleh masih banyaknya siswa yang mengalami kesulitan dalam belajar geometri khususnya segiempat. Tujuan penelitian ini untuk mendeskripsikan proses berpikir siswa kelas VIII dalam menyelesaikan soal segiempat. Jenis penelitian yang digunakan adalah deskriptif dengan pendekatan kualitatif. Metode pengumpulan data yang digunakan adalah tes dan wawancara. Subjek dalam penelitian ini yaitu 2 siswa level visualisasi, 2 siswa level analisis, dan 1 siswa deduksi informal. Hasil yang diperoleh adalah siswa level visualisasi sering mengalami disequilibrium dalam menyelesaikan soal segiempat, namun ketika diberikan penjelasan siswa dapat menyesuaikan, sehingga terjadi equilibrium. Siswa level analisis mengalami disequilibrium ketika mencari hasil penyelesaian soal segiempat, namun setelah terjadi akomodasi, siswa dapat memahami soal sehingga terjadi equilibrium. Siswa level deduksi informal tidak mengalami disequilibrium dalam menyelesaikan soal segiempat, sehingga informasi yang didapat diasimilasi dan mengalami equilibrium.
\end{abstract}

Kata kunci: Penyelesaian soal, proses berpikir segiempat, teori van Hiele

\begin{abstract}
The study came into the background by the many students who had difficulty learning geometry in particular. The purpose of the study to describe the process of eighth graders thinking in resolving a fourth matter. The type of research used is a qualitative approach. The data-gathering method used is tests and interviews. The subject of this study is two visualization level students, two analytic levels, and one informal deduction student. The result is that students of the visualize level are often quelled to settle the matter at a level of four, but when given a student's explanation can adjust, resulting in an equilibrium. Students level analysis has been quizzing when seeking a consensus solution, but after accommodations are underway, students can understand the problem by equilibrium. The students of the informal deduction level have not been quizzed to complete the fourth matter, so the information gained is assimilated and equilibrium.
\end{abstract}

Keywords: the solution, quadrilateral thinking process1, van Hiele's theory

\section{J0M International License. \\ Read online: \\ https://jurnal.unej.ac.id/index.php/JOMEAL/index or scan barcode beside.}

This work is licensed under a Creative Commons Attribution-ShareAlike 4.0

How to cite this article:

Oktaviani, A., Susanto, S., Sugiarti, T., \& Indiyawati, W. (2021). Proses Berpikir Siswa Kelas VIII SMPN 1 Rambipuji dalam Menyelesaikan Soal Segiempat Berdasarkan Teori Van Hiele. Journal of Mathematics Education and Learning, 1(3), 265-273. doi:10.19184/jomeal.v1i3.25985 


\section{Pendahuluan}

Pendidikan menjadi faktor utama untuk memperbaiki kualitas sumber daya manusia. Dalam dunia pendidikan, matematika merupakan materi pelajaran yang penting dan tidak dapat ditinggalkan. Pada proses belajar matematika terjadi proses berpikir (Siswono, 2002). Melalui pembelajaran matematika siswa diharapkan dapat menumbuhkan kemampuan berpikir kritis, logis, sistematis, cermat, efektif dan efisien dalam menyelesaikan masalah. Oleh karena itu, penguasaan materi matematika bagi seluruh siswa perlu ditingkatkan.

Berpikir adalah suatu proses alami dalam diri individu yang dapat membantu menyelesaikan berbagai permasalahan dalam kehidupan. Pembelajaran tidak terlepas dari kegiatan berpikir. Pembelajaran dan perkembangan kognitif terjadi sebagai hasil dua proses yang saling melengkapi, yakni asimilasi dan akomodasi (Ormrod, 2009). Tahap proses berpikir menurut Piaget meliputi: asimilasi, akomodasi, equilibrium, dan disequilibrium.

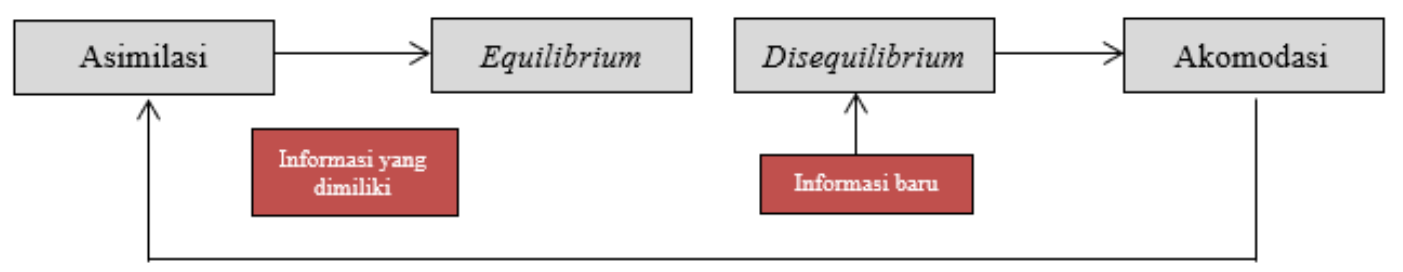

Gambar 1. Tahap Proses Berpikir Menurut Piaget

Pada Kurikulum 13 (K13), salah satu materi geometri yang diberikan pada kelas VIII adalah Bangun Datar. Teori Piaget menyatakan bahwa siswa yang berada pada tahap formal sudah mampu melakukan penalaran dengan menggunakan hal-hal yang abstrak. Siswa mampu bernalar tanpa harus berhadapan dengan objek atau peristiwa langsung (Suherman et al, 2001). Namun, kenyataan di lapangan menunjukkan bahwa materi geometri kurang dikuasai oleh sebagian besar siswa (Kusniati, 2011). Masih banyak siswa yang mengalami kesulitan dalam belajar geometri. Hasil penelitian terhadap 747 siswa terdapat 86,91\% siswa SMP menyatakan bahwa persegi bukan merupakan persegi panjang, dan 64,33\% siswa SMP menyatakan bahwa belah ketupat bukan merupakan jajar genjang (Sunardi, 2011). Hal ini dikarenakan materi yang disampaikan guru tidak bertahan lama dalam ingatan siswa akibat penyampaian pembelajaran oleh guru dilakukan berfokus pada bagaimana cara mengingat materi saja (Siswoyo, 2011).

Kemampuan siswa dalam bidang geometri diungkapkan dalam teori van Hiele. Teori van Hiele adalah hierarki lima level dalam memahami ide spasial dimana setiap level mendeskripsikan proses berpikir yang digunakan dalam konteks geometri. Level berpikir berdasarkan teori van Hiele meliputi level 0 (visualisasi), level 1 (analisis), level 2 (deduksi informal), level 3 (deduksi), dan level 4 (rigor). Setiap level memiliki karakteristik yang berbeda-beda. Tingkatan-tingkatan tersebut menjelaskan bagaimana kita berpikir dan jenis ide-ide geometri apa yang kita pikirkan (Walle, 1994).

Setiap individu dalam menyelesaikan masalah matematika, khususnya geometri memiliki cara yang beragam. Proses berpikir pada setiap individu dimulai dengan memahami masalah, merencanakan cara penyelesaian masalah, dan mencari cara penyelesaian masalah. Dalam menyelesaikan soal segiempat siswa perlu memahami konsep segiempat, apabila siswa tidak dapat memahami soal maka siswa juga tidak dapat menyelesaikan soal tersebut, dan pada akhirnya akan terjadi disequilibrium. Hal ini juga terkait dengan konsep segiempat yang dimiliki siswa tidak terkait 
antara satu dengan yang lainnya. Dalam menghadapi suatu masalah seseorang perlu membuat langkah-langkah mengenai kemungkinan yang akan terjadi dan perlu mengantisipasi terhadap setiap masalah yang dihadapi sehingga akan menghasilkan penyelesaian yang tepat (Sunardi et al, 2015). Terdapat beberapa metode yang bisa digunakan untuk meningkatkan kemampuan berpikir siswa khususnya pada materi segiempat salah satunya metode belajar berdasarkan teori belajar van Hiele. Disebutkan bahwa apabila pembelajaran itu dirancang dengan tepat akan dapat meningkatkan tahap berpikir siswa. Dengan demikian berarti akan dapat meningkatkan pemahaman siswa terhadap konsep yang akan dipelajarinya. Keberagaman setiap individu dalam menyelesaikan masalah khususnya geometri dipengaruhi oleh beberapa faktor, termasuk tingkat berpikir geometri siswa. Teori yang dapat mengklasifikasikan tingkat berpikir geometri siswa adalah teori pembelajaran van Hiele.

Penelitian sebelumnya yang relevan dengan penelitian ini adalah penelitian yang dilakukan oleh Falupi dan Widadah (2016) yang mengungkapkan bahwa dari 32 peserta didik kelas VIII MTsN 1 Sidoarjo yang telah melakukan VHGT terdapat 12 peserta didik berada pada level visualisasi, 18 peserta didik berada pada level analisis, dan masing-masing 1 peserta didik berada pada level deduksi informal dan deduksi. Penelitian ini berbeda dengan penelitian sebelumnya karena materi yang digunakan adalah tes penyelesaian segiempat dan subjek yang digunakan merupakan siswa yang berada pada level visualisasi, analisis dan deduksi informal.

Berdasarkan uraian tersebut dapat dikatakan bahwa proses berpikir siswa dalam menyelesaikan soal segiempat memiliki peran penting dalam menentukan tindakan yang akan diambil dalam menyelesaikan masalah. Oleh karena itu dirasa perlu dilakukan penelitian mengenai proses berpikir siswa kelas VIII SMPN 1 Rambipuji dalam menyelesaikan soal segiempat berdasarkan teori van Hiele.

\section{Metode Penelitian}

Penelitian ini dilaksanakan di SMP Negeri 1 Rambipuji. Penelitian ini menggunakan jenis penelitian deskriptif dengan pendekatan kualitatif. Penelitian tersebut bertujuan untuk mengetahui proses berpikir siswa level visualisasi, analisis, dan deduksi informal dalam menyelesaikan soal segiempat berdasarkan teori van Hiele. Penelitian kualitatif berarti proses eksplorasi dan memahami makna perilaku individu dan kelompok, menggambarkan masalah sosial atau masalah kemanusiaan (Sugiyono, 2017).

Subjek pada penelitian ini adalah siswa kelas VIII SMP Negeri 1 Rambipuji yang berjumlah 5 siswa yaitu 2 siswa level visualisasi, 2 siswa level analisis, dan 1 siswa level deduksi informal. Pengambilan subjek siswa SMPN 1 Rambipuji dilakukan karena masih belum ada penelitian mengenai pelevelan van Hiele di SMPN 1 Rambipuji. Pemilihan subjek tersebut ditentukan berdasarkan pengecekan hasil penyelesaian soal segiempat yang telah dikerjakan siswa dan diskusi dengan guru matematika SMPN 1 Rambipuji. Hal ini dilakukan agar mendapatkan subjek yang bisa diwawancara dengan kemampuan komunikasi yang baik sehingga dapat diwawancarai dengan lancar dan mendapat hasil yang akurat. Lima siswa tersebut diteliti proses berpikirnya dalam menyelesaikan soal segiempat berdasarkan teori van Hiele. Selanjutnya secara berturut-urut subjek pada penelitian ini disebut dengan S1, S2, S3, S4, dan S5. S1 dan S2 merupakan dua siswa yang berada pada level 0 (visualisasi), S3 dan S4 merupakan dua siswa yang berada pada level 1 (Analisis), dan S5 merupakan siswa yang berada pada level 2 (deduksi informal). Instrumen penelitian yang digunakan dalam 
penelitian ini adalah VHGT, tes segiempat dan pedoman wawancara yang berisi pertanyaan yang diajukan kepada subjek penelitian agar dapat menggali informasi mengenai proses berpikir siswa. VHGT dikutip dari Sunardi (2000) sudah valid sehingga tidak perlu dilakukan validasi. Instrumen yang digunakan telah dinyatakan valid dengan skor 8,89 untuk tes penyelesaian soal segiempat dengan skala 10 dan skor 8,92 untuk pedoman wawancara dengan skala 10. Instrumen tersebut divalidasi oleh dua dosen Program Studi Pendidikan Matematika dan salah satu guru matematika SMPN 1 Rambipuji.

Metode pengumpulan data yang digunakan dalam penelitian ini adalah metode tes dan wawancara. Instrumen tes yang digunakan yaitu VHGT untuk menentukan tingkat perkembangan siswa menurut level van Hiele dan tes penyelesaian soal segiempat untuk mengetahui proses berpikir siswa dalam menyelesaikan soal segiempat. Wawancara yang dilakukan mengacu pada pedoman wawancara yang telah dibuat. Peneliti diperbolehkan mengembangkan pertanyaan jika hasil yang diperoleh masih dirasa kurang sesuai dengan tujuan penelitian. Data yang telah dikumpulkan dianalisis dan disajikan dalam bentuk uraian untuk mendeskripsikan topik yang dibahas. Selanjutnya, dilakukan penarikan kesimpulan. Kevalidan data yang diperoleh pada penelitian kualitatif dijamin melalui tahapan triangulasi metode sehingga hasil penyelesaian soal segiempat yang telah dikerjakan dikonfirmasi melalui wawacara.

\section{Hasil dan Pembahasan}

Berdasarkan penelitian yang telah dilakukan di kelas VIII, hasil tes kemampuan berpikir geometri diperoleh 21 siswa pravisualisasi, 26 siswa level 0 (visualisasi), 2 siswa level 1 (analisis) dan 1 siswa level 2 (deduksi informal) persentase secara berturut-turut adalah $42 \%, 52 \%$, 4\%, dan 2\%. Artinya siswa kelas VIII SMPN 1 Rambipuji paling banyak berada pada level visualisasi. Hal ini selaras dengan pendapat Van De Walle yang menyatakan bahwa sebagian besar siswa SMP/MTs berada pada antara level 0 (visualisasi) sampai level 2 (deduksi informal) (Walle et al, 2016). Hal ini diperkuat lagi oleh penelitian terhadap 576 siswa dari 13 SMP Negeri di Jember yang menunjukkan bahwa persentase responden pada tingkat visualisasi, analisis, deduksi informal, deduksi, dan rigor berturut-turut adalah $44,62 \%$; 34,55\%; $6,77 \%$; $0,17 \%$; dan $0 \%$ serta $14.40 \%$ dari siswa tidak dapat diklarifikasi ke salah satu dari level (Sunardi, 2002).

Subjek pada penelitian ini dipilih berdasarkan tes level kemampuan berpikir siswa dalam geometri yaitu berjumlah 5 siswa diantaranya 2 siswa level visualisasi, 2 siswa level analisis, dan 1 siswa level deduksi informal. Selanjutnya, subjek penelitian dihadapkan dengan 3 soal tes segiempat dengan waktu pengerjaan 60 menit. Tes penyelesaian soal segiempat dapat dilihat pada gambar 1 berikut.

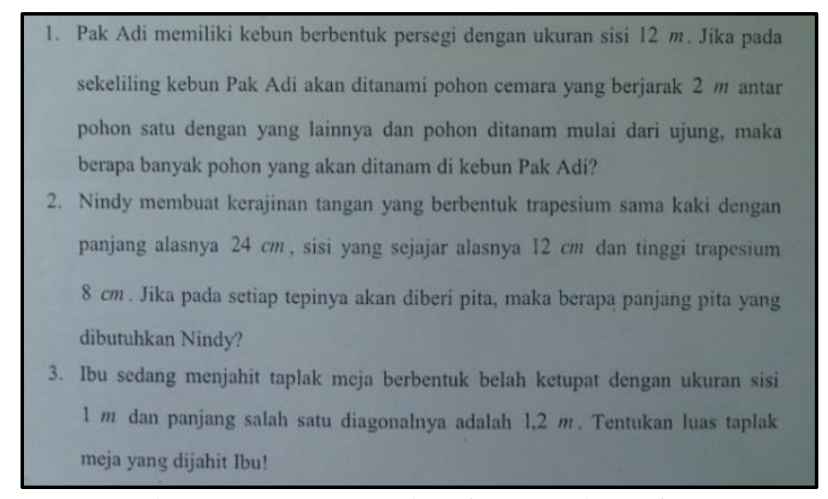

Gambar 1. Tes Penyelesaian Soal Segiempat 
Kemudian dilakukan wawancara untuk mengetahui proses berpikir siswa. Hasil analisis menunjukkan bahwa masing-masing subjek berbeda dalam proses mengerjakannya. Selain itu, setiap subjek berbeda pula proses berpikir yang dialami ketika melewati setiap tahapan Piaget.

Berdasarkan hasil analisis terhadap proses berpikir siswa, diketahui bahwa kelima subjek mengalami serangkaian proses berpikir yaitu disequilibrium, asimilasi, akomodasi, dan equilibrium. Proses berpikir S1 dan S2 pada level visualisasi dalam menyelesaikan soal segiempat adalah siswa mampu mengidentifikasi hal-hal yang diketahui dan ditanyakan pada soal dengan benar (asimilasi). S1 dan S2 dapat menggambar sketsa bangun yang diminta pada soal dengan benar (asimilasi). Hasil ini menunjukkan kesamaan dengan dengan penelitian sebelumnya bahwa siswa pada level visualisasi dapat mengidentifikasi, menggambar bangun segiempat berdasarkan penampakan visualnya (Khumayroh et al, 2019). Hasil penyelesaian salah satu siswa level visualisasi dapat dilihat pada Gambar 2.

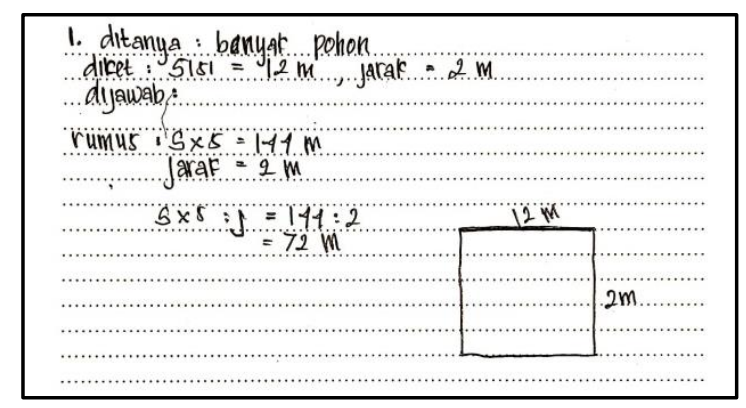

Gambar 2. Hasil Penyelesaian Soal Segiempat Siswa Level Visualisasi

Dapat diidentifikasi bahwa siswa masih bingung untuk membedakan rumus keliling dan luas pada bangun segiempat (disequilibrium) sehingga hasil penyelesaian soal segiempat yang diperoleh tidak tepat. Tetapi terdapat perbedaan antara S1 dan S2 meskipun kedua subjek berada pada level yang sama. Perbedaannya adalah S1 dapat menyebutkan sifat dari bangun persegi meskipun tidak secara rinci (asimilasi) sehingga S1 dapat dikatakan mengalami tahap perkembangan menuju level analisis. Sedangkan S2 masih bingung menyebutkan sifat dari bangun segiempat (disequilibrium). Hal tersebut terlihat dalam cuplikan wawancara berikut.

P06:14 Baik, coba sebutkan sifat-sifat trapesium apa saja?

S206:20 (terdiam 3 detik) em.. memiliki diagonal yang sama, ehh iya ta

P06:25 Boleh, apabila trapesium sama kaki, maka diagonalnya sama, lalu?

S206:36 Empat sisi, terus sisi yang itu 180 derajat

P06:38 Sisi yang bagaimana?

S206:41 Yang apa ya, lupa Bu soalnya

P06:43 Sisi yang sejajar ada berapa?

S206:46 Ada dua

P06:54 Apakah itu sejajar?

S206:59 Em.. kayaknya iya sih (menunjuk sisi miring pada trapesium)

Berdasarkan uraian diatas, proses berpikir siswa level visualisasi dapat dilihat pada gambar 3 berikut. 


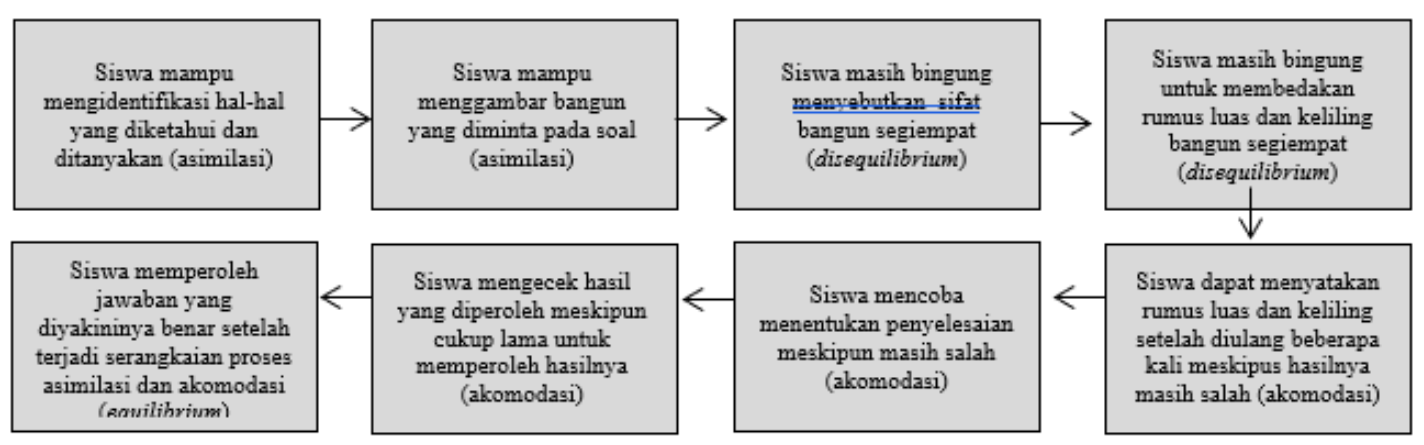

Gambar 3. Proses Berpikir Siswa Level Visualisasi

Proses berpikir S3 dan S4 pada level analisis dalam menyelesaikan soal segiempat adalah siswa mampu mengidentifikasi hal-hal yang diketahui dan ditanyakan pada soal dengan benar (asimilasi). S3 dan S4 dapat menggambar sketsa bangun yang diminta pada soal dengan benar (asimilasi). S3 dn S4 dapat menyebutkan sifat dari bangun persegi (asimilasi). Hasil ini menunjukkan kesamaan dengan dengan penelitian sebelumnya bahwa siswa pada level analisis mampu mengenal nama bangun datar dan mampu menyebutkan sifat dari bangun datar (Falupi et al, 2016). Siswa masih bingung untuk membedakan rumus keliling dan luas pada bangun segiempat (disequilibrium). Setelah diam sejenak (akomodasi), S3 dan S4 mampu membuat langkah penyelesaian soal. S3 dan S4 kurang teliti dalam menyelesaikan soal segiempat sehingga hasil yang diperoleh menjadi kurang tepat (akomodasi). Hasil penyelesaian salah satu siswa level analisis dapat dilihat pada Gambar 4.

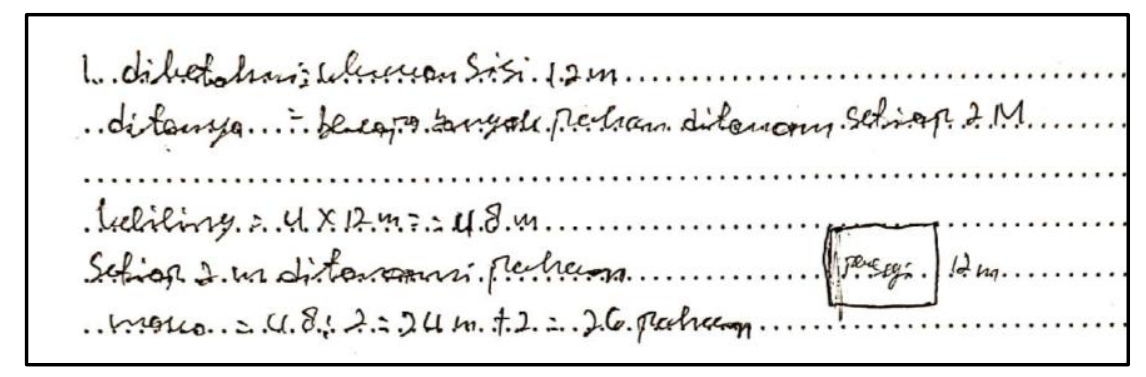

Gambar 4. Hasil Penyelesaian Soal Segiempat Siswa Level Analisis

Berdasarkan uraian diatas, proses berpikir siswa level analisis dapat dilihat pada gambar 5 berikut.

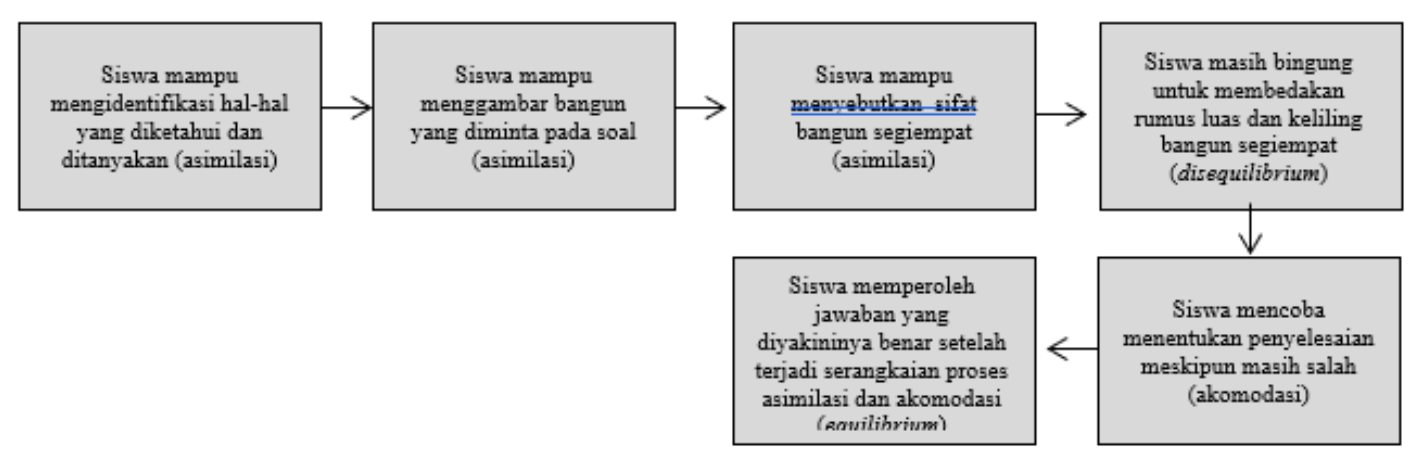

Gambar 5. Proses Berpikir Siswa Level Analisis 
Proses berpikir S5 pada level deduksi informal dalam menyelesaikan soal segiempat adalah siswa mampu mengidentifikasi hal-hal yang diketahui dan ditanyakan pada soal dengan benar (asimilasi). S5 dapat menggambar sketsa bangun yang diminta pada soal dengan benar (asimilasi). S5 dapat menyebutkan sifat dari bangun segiempat dengan baik dan benar (asimilasi), namun S5 masih belum mengetahui hubungan sifat-sifat pada bangun segiempat. Hal tersebut terlihat dalam cuplikan wawancara berikut.

P01:22 Oke, dari sifat-sifat yang telah disebutkan, apakah boleh bangun tersebut saya katakan bangun persegi panjang?

S501:24 Enggak bisa Bu

P01:25 Mengapa?

S5001:43 Karena kalau persegi kan semua sisinya sama panjang, kalo persegi panjang kan ada yang dua itu sama panjang yang dua lagi juga, kan dua pasang sisi, yang satu pasang seumpama 12 yang satu pasang lagi 16 jadi beda

P01:46 Ohh panjang sama lebarnya beda?

S501:47 Beda

P02:05 Oke, kalau misalkan saya punya persegi panjang dengan sisinya 12 dengan 12, boleh gak?

S502:06 Enggak bisa Bu

P02:07 Harus beda?

S502:08 Iya

S5 mampu membuat langkah penyelesaian masalah serta mampu memberikan alasannya dengan lancar dan benar (asimilasi). Selanjutnya, S5 mampu melakukan perhitungan dengan benar hingga memperoleh hasil dari soal segiempat (asimilasi). Hasil penyelesaian siswa level deduksi informal dapat dilihat pada Gambar 6.

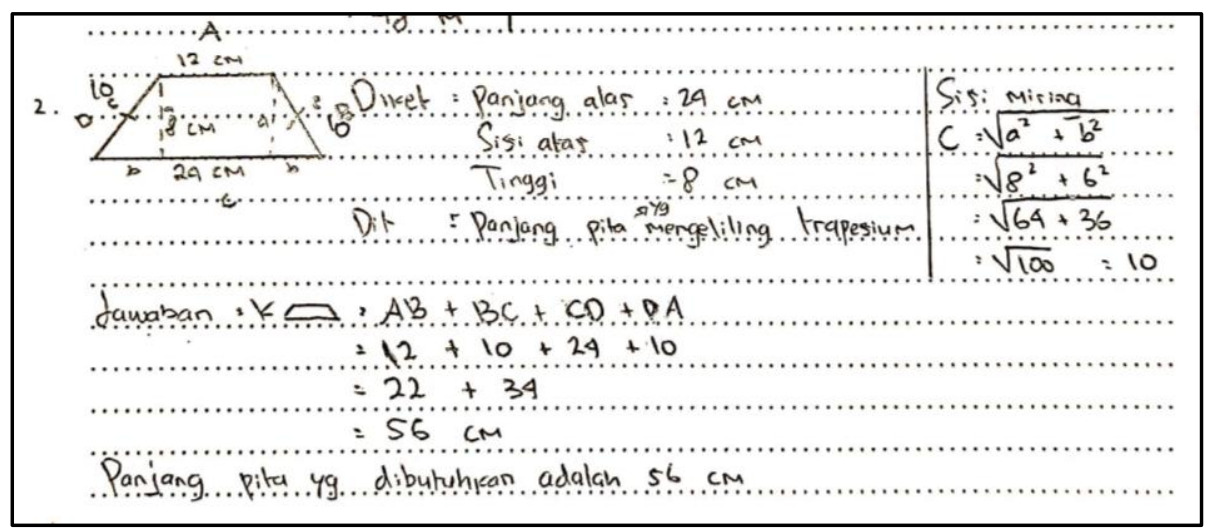

Gambar 6. Hasil Penyelesaian Soal Segiempat Siswa Level Deduksi Informal

Berdasarkan uraian diatas, proses berpikir siswa level deduksi informal dapat dilihat pada gambar 7 berikut. 


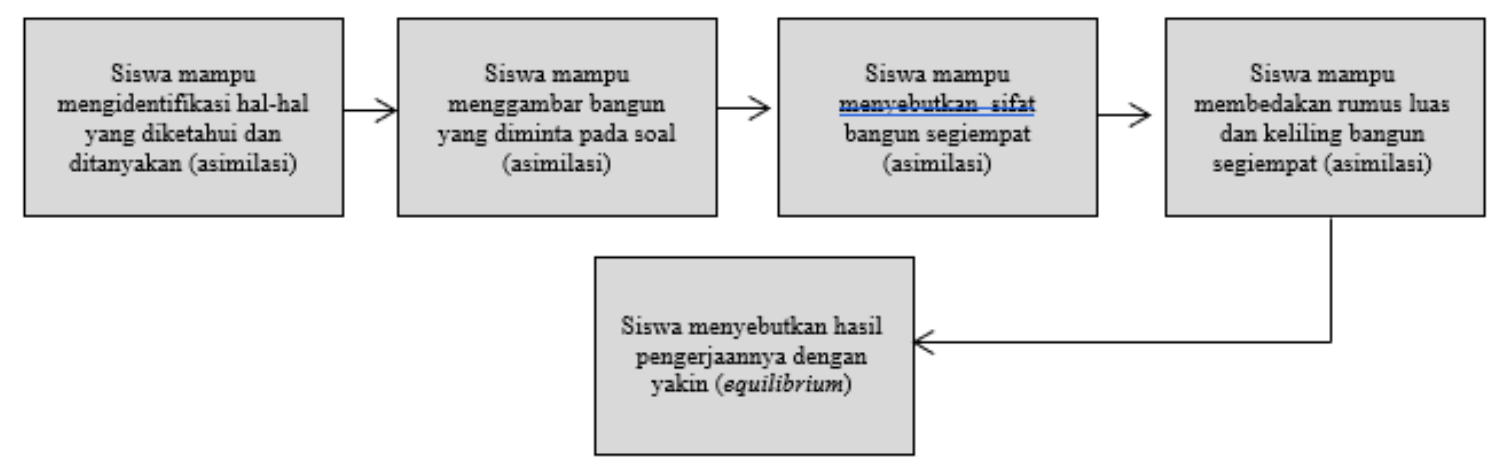

Gambar 7. Proses Berpikir Siswa Level Deduksi Informal

\section{Kesimpulan}

Berdasarkan hasil analisis dan pembahasan, maka diambil kesimpulan mengenai proses berpikir siswa kelas VIII dalam menyelesaikan soal segiempat berdasarkan teori van Hiele. Siswa level visualisasi sering mengalami disequilibrium dalam menyelesaikan soal segiempat, namun ketika diberikan penjelasan siswa dapat menyesuaikan, sehingga terjadi equilibrium. Siswa level analisis mengalami disequilibrium ketika menentukan hasil penyelesaian soal segiempat, namun setelah terjadi akomodasi, siswa dapat memahami soal sehingga terjadi equilibrium. Siswa level deduksi informal tidak mengalami disequilibrium dalam menyelesaikan soal segiempat, sehingga informasi yang didapat diasimilasi dan mengalami equilibrium. Berdasarkan penelitian yang telah dilakukan, hal yang perlu dipertimbangkan untuk penelitian selanjutnya yaitu diperlukan penelitian lebih lanjut mengenai bagaimana cara untuk mengembangkan kemampuan penyelesaian soal yang dimiliki siswa.

\section{Daftar Pustaka}

Falupi, D. V., dan Widadah, S. 2016. Profil Berpikir Geometris Pada Materi Bangun Datar Ditinjau Dari Teori Van Hiele. Jurnal Pendidikan Matematika STKIP PGRI Sidoarjo. 4(1): 1-8.

Khumayroh, A.A, dkk. 2019. Karakteristik Berpikir Geometri Siswa Pada Tingkat Visualisasi, Analisis, dan Deduksi Informal Berdasarkan Teori van Hiele. Kadikma. 10(3):15-27.

Kusniati. 2011. Analisis Kesalahan Siswa dalam Menyelesaikan Soal Materi Pokok Segiempat Menurut Tingkat Berpikir Geometri Van Hiele. Skripsi. Semarang: Fakultas Matematika dan Ilmu Pengetahuan Alam.

Ormrod, Jeanne Ellis. Educational Psychology Developing Learners. Terjemahan oleh Wahyu Indianti, dkk. 2009. Psikologi Pendidikan Membantu Siswa Tumbuh dan Berkembang. Jakarta: Erlangga.

Siswono, Tatag Yuli Eko. 2002. Proses Berpikir Siswa dalam Pengajuan Soal. Jurnal Matematika atau Pembelajarannya. XI: 22-25.

Siswoyo, B. 2011. Peningkatan Hasil Belajar Sifat-Sifat Segiempat dengan Pendekatan STAD (Student Teams Achievement Divisions) di Kelas VII-1 SMP Negeri 2 Kutalimbaru. Jurnal Kreano. 2(2): 89-102.

Sugiyono. 2017. Metode Penelitian Kualitatif. Bandung: Alfabeta CV.

Suherman, Erman dkk. 2001. Strategi Pembelajaran Matematika Kontemporer. Bandung: JICA. 
Sunardi. 2002. Hubungan antara Tingkat Penalaran Formal dan Tingkat Perkembangan Konsep Geometri Siswa. Jurnal Ilmu Pendidikan. 9(1): 43-54.

Sunardi. 2011. Pembelajaran Geometri Sekolah dan Problematikanya. Jember: Prosiding Seminar Nasional Matematika dan Pendidikan Matematika.

Sunardi dan Yudianto, E. 2015. Antisipasi Siswa Level Analisis dalam Menyelesaikan Masalah Geometri. Jurnal AdMathEdu. 5(2):203-216.

Walle, V.D. 1994. Elementary School Mathematics. New York: Longman.

Walle, J. A. Van De, Karp, K. S., dan Wray, J. 2016. Elementary and Middle School Mathematics Teaching Developmentally 9th Edition. United States of America: Pearson Education. 